\title{
Materiality, Territory and Sovereignty: Responding to Contradictory Water Security Issues in the Mekong Region
}

\author{
IAIN WATSON* AND JULIETTE SCHWAK ${ }^{* *}$
}

\begin{abstract}
Aspirations for sub-regional, regional and global cooperation at a bi-lateral and multilateral level over water security are strong and yet often a real or perceived gap exists between intentions and the workings of institutions. In the area of water security difficulties are often premised on tensions between national territory and national sovereignty. As a result, emphasis has been placed by decision makers on how to most effectively classify the 'most at risk' areas from water security issues. However, this objective itself is often separated from wider issues of economic land ownership. Yet stakeholders paradoxically have both similar and yet different understandings of what counts as territory and sovereignty. A majority of stakeholders continue to pursue a 'realist' or liberal approach to the spaces of national sovereignty and territory as water course or water basin. This binary assumption of territory as a specifically bounded political space is given here as a reason for limited concrete results on water security governance. Recalibrating this understanding of sovereignty, territory and security through a sociology of materialism might therefore open alternative spaces for ensuring issue-specific governance in spaces now impacted by the dynamics of infrastructure and sub-regional connectivity. By framing these tensions through the issue of territory and materialism the paper identifies gaps and strategic opportunities emerging that might potentially recalibrate the conceptual and policy debate on water security and its territorial assumptions.
\end{abstract}

Keywords: Water Security, Materialism, Cooperation, Territory

*Associate Professor, Ajou University, Suwon, South Korea;

E-mail: i.watson@hotmail.co.uk;

**Assistant Professor, Franklin University, Switzerland, E-mail: jschwak@fus.edu;

DOI: 10.16934/isr.21.1.202006.25 


\section{INTRODUCTION}

Stakeholders and diplomats may not use the term or concept of new materialism in their everyday bargaining on water security. However, the paper will argue here that there is emerging a potential infiltration of this new material theme in the context of climate change and water security and following other approaches in terms of the theory-practice relationship. This is particularly the case with regard to the relationship between climate change and physical boundaries such as rivers and coasts that often delineate physical space as land or sea as state territory in their 'natural' and everyday experienced routines. In the context of water security and disaster risk reduction (OECD 2013; UNDP 2004; UNISDR 2009; UN-Water 2013) I will identify a number of diplomatic tensions emerging at a bi-lateral and multilateral sphere. Such inter-state bottlenecks can typically occur over issues of fair (although not necessarily equal) water usage, the blocking of river water flow upstream (either deliberately or unintentionally), the 'over' use of water as a resource (agriculture or industry), externalities of water pollution and the taking of sovereign responsibilities. Yet these institutional issues are characterised by similar assumptions as to the site and nature of sovereignty, territory and the interrelationship between them.

For realists, generally, the axiom 'good fences make good neighbours' informs a focus on protecting and reinforcing state sovereignty from national security threats through bi-lateral or multilateral formats. Liberals tend to regard climate change as the ultimate in new transboundary issue agenda in an age of complex interdependence and therefore favour a more 'pooling' sovereignty approach to inter-state relations. This enables institutional brokerage and cost-effective cooperation as a result of recognised and issue specific state vulnerability and sensitivity. By opening the issue of exploring the 'is' of territory the paper takes a different angle to explaining the water security debate and its current policy parameters.

Growing regional concerns often ensue between upstream and downstream riparian sovereign states (and domestically between upstream and downstream sub-regions within sovereign territorial riparian states). The UN legalised 'water' as a human right on 28 July 2010 as being affordable, clean and accessible to all. Yet issues regarding type of stakeholder private (individual or business) or public, were ostensibly minimalised or put under the rubric of 'diverse' interests without acknowledging the issue of unequal power relations and distribution. Water security is defined by UN-Water $(2013,1)$ as "The capacity of a population to safeguard sustainable access to adequate quantities of acceptable quality water for sustaining livelihoods, human well-being, and socio-economic development, for ensuring protection against water-borne pollution and water-related disasters, and for preserving ecosystems in a climate 
of peace and political stability." This also means that local distributional issues and quality of supply may also lead to a spate of negative regional contests (Gleick 1993, 1998).

Available water resources (per capita) around the world has declined by more than half since 1960. Yet global demand for fresh drinking water is expected to exceed supply by $40 \%$ by 2030 . It has been reported recently that $60 \%$ of fresh water is supplied by transboundary river basins but only $40 \%$ of the basins have mechanisms for pre-emptive conflict resolution between states. However, placing the centrality of water as a key issue of national and global security generates concern that if populations do have good access to good quality drinking water then other issues are de-politicised or causally linked to the issue of water rather than to structural issues of land ownership/distribution, ethnic group land rights, neoliberal constitutional land reforms and the consequences of neoliberal structural reforms.

In the Anthropocene of climate change, national and global water security policies are often tied to disaster risk reduction strategies (Latour 1992, 1999). This can be an issue for competition states and national 'soft power' branding strategies in the neoliberal context where local ethnic conflicts do not augur well for investment attraction. A tension is now emerging between the securing and protection of the physical materiality of territory (crops, soil, groundwater, rocks, clay, silt, sand, vegetation, nutrients and food) and the abstract 'realist' understanding of bounded and legal territorial sovereignty. This paradox is not only manifested as increasing geopolitical tensions between upstream and downstream states in the Mekong region (such as hydro-electric power dams) but also between sub-national upstream and downstream local spaces within national territorial sovereign space (Allen 2011; Antonsich 2009, 2010, 2016; Beurskens et al 2017).

As a result, the paper considers as to what might potentially happen to water security cooperation when an alternative approach to the assumptions of what counts as terrain and territory is enacted. Rather than engaging in debates over measuring and designating as to what counts as risk or vulnerability the paper re-considers the one major assumption that belies all these water security policies (water course and water basin) namely that territory 'is' a fixed and bounded surface space upon which 'surface' water security issues impact (Magsig 2015). Usher (2019) recently pointed out that through a new material approach the concept and notion of territory is not merely understood as a produced and technical space on which centralised Westphalian sovereign (or constitutional law) is enacted but, instead, is a physical re-working of land through various cultivation practices and the constantly shifting and rearranging of sub-atomic particles. 
The Westphalian assumption (and the assumption that Westphalia produced this understanding) of territory as a bounded space informs the inter-state tensions between watercourse and water basin responses to riparian issues and wider water security. There have been over the years many challenges to this notion, firstly on the basis of what the Westphalian peace really did say (the 'origin myth' argument), the issue regarding potentially emergent non-Westphalian systems or regions (such as issues of divergence and de-coupling) and the wider 'critical theory' challenges to the mainly neorealist view of the Westphalian system.

Firstly, the 'water course approach' conceives of a river flowing into a national territory within the space of enclosed boundaries so that the state has full sovereign jurisdiction over a part of a river that flows within these spatial bounds at a specific moment of time. At the designated 'snapshot' of time the water of the river flowing within these territorial boundaries is under the control and responsibility of the spatio-temporal and sovereign state apparatus. This represents the Westphalian understanding of an international system based on the particulars of fixed national spaces each with time flowing through it.

Secondly, the water basin approach emphasises a 'shared sovereignty' and a transboundary approach to water security. Yet both approaches similarly maintain a shared and conventional assumption of what territory. Thus, territory is in effect understood as a term concept and as a physical space that is defined by and resides within physical boundaries (Xie and Jia 2017).

The paper argues that the spatial limits of the Westphalian based water security might, however, help recalibrate understandings of territory and jurisprudence sovereignty and enable a genuinely realistic approach to the impact of climate change on riparian states. The paper is therefore initially placed in the literature on disaster resilience and water risk security. (Anderson et al 2011, 2012; Bandvopadhyay 2013; Benson et al 2001; Bingham et al 1994: Manyena 2016; Mavelli 2016; Salter and Walters 2016; Shah 2011; Sohn 2016). The paper then shifts from this literature to identify the policy disagreements in the context of rethinking territory through a new materialism approach.

In the first section the context of disaster risk reduction and regional water security is outlined. Next, the paper considers the key spatial assumptions regarding the relationship between territory and water security in terms of the water course and water basin approaches. The paper then outlines critical territory approaches and the contemporary context of the 'new materialism' as a means of rethinking and unlocking the strategic binaries of the current water security. The paper then outlines a number of possibilities with regard to questioning the non-physical and abstract assumptions of what territory 'is' and should be. 


\section{DISASTER RISK REDUCTION AND WATER SECURITY}

The OECD (2013) identified four main risks to water security including:

Risk of shortage (including droughts): lack of sufficient water to meet demand (in both the short- and long-run) for beneficial uses by all water users (households, businesses and the environment); Risk of inadequate quality: lack of water of suitable quality for a particular purpose or use; Risk of excess (including floods): overflow of the normal confines of a water system (natural or built), or the destructive accumulation of water over areas that are not normally submerged; Risk of undermining the resilience of freshwater systems: exceeding the coping capacity of the surface and groundwater bodies and their interactions (the "system"); possibly crossing tipping points, and causing irreversible damage to the system.

Blackbourn $(2006,7)$ once noted that "With mastery of water comes the opportunity for conflict over it." Yet inter-state and regional conflicts over water usage, access, protection and equitable (or fair) distribution are often about having a lack of mastery over the environment in the era of climate change. Water security is approached as the reliable availability of an acceptable quantity and quality of water for health, livelihoods, and production but with an acceptable level of water-related risks (Grey and Sadoff 2007). Mollinga (2008, 7) notes that "Freshwater resources management by definition is a context-specific phenomenon, given that it concretely happens through managing river basins, aquifers, landscapes and ecosystems" but "the "problemsheds" and "issue networks" of water resources management may stretch well beyond the physical boundaries of these units and span the globe and history.' As Mollinga $(2008,10)$ goes on to note, water control "is at the heart of water resources management and should be conceived as a process of politically contested resource use" (original emphasis).

The year 2013 was declared by the United Nations (UN) as the 'International Year of Water Cooperation.' As a result, the notion of maintaining the responsible 'stewardship' of water supply is central to issues of ensuring water security for all in the 2015-2030 Sustainable Development Goals (SDG) era. In market liberalist terms water is understood as a scarce and finite resource (or commodity) that requires proper allocation of resources through the price mechanism. Issues of water privatization, access and fair pricing are key issues emerging from this, as well as the role of the state in regulating the water industry and industrial pollution over drinking supplies (human security). Traditional techniques such as water divining are increasingly 'commodified' and regarded by the UN as a key to local community water resilience response. Green 
technologies of 'water capture' are also typically used to enhance water storage capability, resource capacity and techniques of purification (Bingham et al 1994). From this emerge the cultural and ethical issues of defining what counts as equal access to water as issues of water justice and water rights, as well as avoiding the 'tragedy of the commons' Moreover, issues of types of pollution into underground rocks and aquifers that may geologically across surface state boundaries (and diverse stakeholder interference with the water cycle even if well intentioned) means that the issue of water security over resource and monitoring usage is tied to international, bi-lateral and regional-based cooperation (Gleick 1993, 1998). Paradoxically, the likelihood of more regulation and governance can increase water consumption before legislation is put in place, worsening the situation of scarcity as a 'use it or lose it' mentality. These demands have often required reforming institutions for addressing collaborative management techniques and is often based on making diplomatic and intra-institutional trade-offs, managing free rider and externality issues, issues of sharing sensitive information between competitive government agencies, methods of cost effectiveness and identifying opportunity costs for institutional facilitation and enabling. Cooperation is usually based on accelerating and ensuring cost effectiveness, transparency of information, and the role of a mediator state. This approach is further based on responding to the changing integrity of the hydrological cycle(s). Emphasis on water security is often placed on a regions' capacity to handle future water shocks through better data gathering and early warning technology. The 'water justice' question regards the issue of the equitable use of water by each state in conjunction with variations in each state's supply of water at a given time. The issue of access to and amount of water supply allowed at a certain rate and designated time period typically brings in tensions if one state may increase storage capacity to withstand future shocks but in effect deprives the neighboring state of having an equitable access. To determine the level of what 'equitable' means governance has been based on having access to each state's national knowledge and data on water supplies. This can often be viewed as a threat to a smaller state's national sovereignty. This is particularly sensitive if water supplies are regarded as a means of providing the scientific information from another state so as to be able to identify areas of rare earth minerals or to locate subterranean geological spaces for extractive industries.

\section{SOUTH EAST ASIA AND WATER SECURITY}

The Mekong River Basin (MRB) is home to more than 70 million people who live in the six riparian countries: China and Myanmar (in the Upper Mekong Basin) and Thailand, Lao PDR, Cambodia and Vietnam (in the Lower Mekong 
Basin). These states are also South East Asian states, leading to issues regarding regional identity and cooperation on this basis. Many countries also self-define as ASEAN states, further leading to the possibility that each state has variations of policy depending on self-defining as South (East) Asian, ASEAN member or Mekong based (as a member of the Mekong River Commission). The recently updated Mekong 'Basin Development Strategy' (2016-2020) prioritizes joint-projects between members within the context of the institution and provides directions for planning and integrated development and management of the Cambodian and Vietnam Mekong delta. In 2016 the 'Master plan of ASEAN Connectivity 2025' was announced in Laos and prioritised the regional constructing of sustainable infrastructure, digital innovation, seamless logistics/infrastructure and "establishing regional regulatory excellence by 2025." It also stated (ASEAN 2016, 5) that "Connectivity in ASEAN encompasses the physical (e.g., transport, ICT, and energy), institutional (e.g., trade, investment, and services liberalisation), and people-to-people linkages (e.g., education, culture, and tourism) that are the foundational supportive means to achieving the economic, political-security, and socio-cultural pillars of an integrated ASEAN Community."

Countries in the further Asian sub-region of what is approached as 'the Mekong region' are typically understood as upstream, downstream, higher basin or lower basin delta states. Indeed, this brings in the issue of defining regions as objective spatial entities or through identity and perception. The question often raised further regards the equitable use of water as a bi-lateral issue, as a regional neighborhood issue, as a multilateral and institutional regional issue or as a wider trans-boundary international issue (Paladini 2012; Pink 2016; Rieu-Clarke and Gooch 2010). The Mekong River might be regarded as a knitter (or connector) of physical lands or as a natural and physical border that divides similar forms of geological land in different states into separate Westphalian and fixed territorial sovereign states. The Asian Development Bank's Water Management Strategy is to encourage greater river health monitoring at the territorial 'watercourse' country and river basin levels. What is termed the 'KD5' resilience to waterrelated disasters Asian Development Bank Water Resource Management strategy has now indicated that the advanced economies often demonstrate the strongest performance in risk reduction whereas the rest of the Asia-Pacific has weak resilience. This is the possibility of the exploitation of the water security issue for non-water security issues by groups and elites which can be used to justify pushing through non-water based economic and neoliberal policies. The Asian Water Development Outlook (AWDO) has been prepared by the Asian Development Bank (ADB) to highlight the challenges of water management in the Asian-Pacific region as a regional issue. For instance, the Asian Development Bank's 'Key Dimension 5 (KD5)' represents an assessment of a nation's "Resilience to Water-Related Disasters" as calculated by 'indicative' factors. The 
International Centre for Water Hazard and Risk Management (ICHARM) has also developed a data-driven mathematical methodology for assessing a nation's resilience to water-related disasters. As a result, the use of data and metrics can induce a sense of national 'disaster competitiveness' where resources are provided only to those areas that can be easily quantified as vulnerable. There are also changes in the hydrological cycle associated with global warming such as sea-level rises with changes in storm patterns, precipitation and freshwater availability. Mekong states typically see a water basin approach as a threat to national territorial integrity and a strategic ruse from the more dominant 'water hegemonic' states.

The water basin versus watercourse is a diplomatic tension on the basis of national sovereignty, and an understanding of territory as a bounded space and, therefore, remains a key source of domestic and intra-state contentions between sub-national spaces within different national territories and between sovereign states. At the same time, water resources are still mostly managed within the boundary of individual economic sectors and the domestic provinces as opposed to an integrated river basin management system. Paradoxically, however, through the use of infrastructure (and the building of DRR evacuation routes) in the connecting of sub-national spaces within and between national territory, the geological shifts in watercourse direction are also putting an extra pressure on the contradiction between watercourse (flowing through the national land territory) and water basin approaches (a collection land within and crossing the borders of sovereign states.

The Mekong is therefore commonly known as the "battery of Southeast Asia' given its acknowledged hydropower potential for riparian Mekong states. Yet hydropower construction is clearly controversial as it is potentially stopping water (and sediment flows) from upstream states to the downstream agricultural delta. Too much water release causes flooding whilst too little and agricultural crops are negatively impacted. The construction of dams is justified by water course sovereign rights over the river within territorial boundaries and where the dams and river rate at that specific time are located and recorded. No sediment flow also means rising seas and rivers and a clear fish supply depletion.

Despite multilateral interest there is, however, a trend towards regional bi-lateralism even if the transboundary reality is creating networks of institutional cooperation. China is clearly heavily investing in the 'belt and road' with Japanese investment in economic highway construction corridors. The construction is creating deforestation leading to the threat of more river flooding whilst Chinese dams (argued to help 'green' China come off coal power) have been blamed for reductions in Mekong flow to the downstream and delta riparian states. Indeed regional states can often use the global agenda of combating climate change to legitimate more locally controversial policies that aid economic 
and transnational elite network interests. At the same time, a dried Mekong riverbed would also make future highway construction cheaper and without the need for costly bridges indicating again the local and global contradictions between development and the environment are ultimately manifested accelerating at the material local level. Moreover, slowing river flow is leading to the build-up of sediments and the creation of small islands along and within the river-course. This is potentially leading to an issue of shifting physical borders of states and territorial claim disputes at points where the Mekong is the international border (such as between Myanmar and Laos and between Laos and Thailand). Thus, there is emerging from this a key governance tension between national sovereignty, sub-regional space and trans-boundary issues as a water course (flowing through a bounded space) and water basin (transboundary collaboration). The Mekong river is understood as a space 'in itself' that is greater than the "sum of the sub-national parts" and national territory but also as a sub-national territory under the jurisdiction of national sovereignty. A certain level of water scarcity may incentivize cooperation, but as scarcity increases the benefits of cooperation may diminish and lead to conflict. This, as a result, is creating and reinforcing contradiction between the Westphalian mapping of the region in legal sovereignty claims and the material shifts in river hydrology.

It was in 1995 that the Mekong River Commission (MRC 1995) was founded by the four sovereign nations (Cambodia, Thailand, Laos and Vietnam) in the sub-region of South East Asia. Emphasis by the MRC has been, we found, from the very outset, put on managing the 'equitable' use of Mekong river water on the basis of preserving national interest and natural water resources. This effort is placed within existing territorial boundaries and under national territorial sovereignty. The 1995 Mekong Agreement (MRC 1995, 2) aims "to promote, support, cooperate and coordinate in the development of the full potential of sustainable benefits to all riparian states and the prevention of wasteful use." The 'equitable utilization' approach of the Mekong's water flow is to be achieved through 'notification' and 'prior consultation' among the basin states. The Mekong is therefore defined here as a watercourse flowing through a specific territory at a pre-determined and agreed upon specific 'snapshot' time. As a result, the river (and its tributaries) is disconnected from geological, hydrological, chemical, and biological linkages with adjacent land areas. This also makes the water course approach placed in a tension with and between wider DRR sub-national linkages within and between states and geological connections between sub-regional zoning between physical spaces within territorial states. The water course approach that is favoured by the MRC invariably means that this issue of equitable usage is separated from wider national land ownership issues. Such legal and sovereign contests might simultaneously represent the tensions between legal (and abstract) Westphalia understandings of territory, 
borders and sovereignty and the local realities of material 'churnings.' Indeed, even through an abstract Westphalian approach it is increasingly acknowledged that physical materiality does play a part in determining the 'reality' of borders and type of land that is more or less susceptible to climate change extremes. Some riparian states in the region also have more physically designated 'Mekong space' than others flowing in and through their own bounded and national territory. This means that trans-boundary (or water basin) governance for these states could lead to a greater intervention and monitoring by international bodies of their sovereign territory. The MRC is therefore predicated on the water-course approach to respect territorial boundaries. The debate is set up in binary terms with both perspectives paradoxically making similar assumptions about territory. The Mekong sub-region is therefore both made up of the subnational territorial spaces in separate states whilst simultaneously existing through different territorial states that make up a sub-region designated as the Mekong. This leads to the question as to whether the Mekong space within each national territory can be in effect 'abstracted' from its geological moorings as something 'greater than the sum of the parts.'

\section{MATERIAL TERRITORY AND WATER SECURITY}

Firstly, the new materialism approach breaks water itself down into its sub-atomic, molecular and organic worlds and by doing this is undermining the abstract assumption of what counts as a surface water flow (as mapped and located in riparian sovereign and Westphalian law). As Endfield and Lieshout $(2020,73)$ recently point out, inter-state and local/transnational conflicts over issues of drainage, usage, storage and access are often played out "on rights over water" and between "the horizontal and volumetric understanding of resource ownership and access" which has also meant that "flowing water became an increasingly contested resource, accompanied by complex litigation and a shift in common law towards the notion that water rights could be appropriated through usage." This approach has also impacted on the tension between local tradition and custom laws of land rights/ownership and new national and centralised authority-based laws of disaster risk over a "moving, flowing good." This has often meant constant clashes between different formulations of "ownership and territory" (Endfield and Lieshout 2020, 78).

Secondly, Stuart Elden $(2013,35)$ argues that territory is "not merely a cognate of land, a political-economic term implying ownership, exchange and use value, distribution, partition, division" but there is also a "strategic, political dimension to the term, understanding the power relations in a narrow sense of contestation and struggle" with power understood as "the legal and the technical". 
Similarly, Usher (2019) notes that territory is an ecological as well as spatial entity insofar as environmental attributes can make a given territory more or perhaps less amenable to cultivation. A material turn to territory challenges the conventional idea of territory with its narrow Westphalia preoccupations with enclosure and borders and with the notion of sovereignty emanating out to the edge of the border or hinterland from a sovereign centre.

Thirdly, conventional territory studies tend to regard territory as a natural physical space based on human behaviour and a physical space that is contained and bounded by recognised borders over which a sovereign actor exercises power. Yet historically it has also been evident that not all territories are necessarily bounded spaces and not all bounded spaces are necessarily territories (Elden 2009). These processes are usually understood as technological productions of physical space and physical border construction which are named and represented as legitimate in historically specific ways. This is the challenge to what John Agnew (1994) had termed 'the territorial trap' (Shah 2011).

Fourth, Elden (2010) notes that territory 'is' (or can 'be') understood as a terrain (military-strategic), as technically bounded and under surveillance (mapping, representations and organised) as well as legal and/or economic issues of ownership (Elden 2010, 2013, 2013a). A boundary is conventionally understood as a line of 'nominally zero width' that divided territories from each other. Moreover, the actual physical maintenance and materiality of the border (flag, gate, cement wall, barbed wire, river or mountain) can also have representational and political connotations of permanence or impermanence. As a result, territory is a bundle of political technologies that regulate myriad relations between people(s), places and power (Elden 2010). For Elden $(2017,21)$ "material processes are transforming territory" and this "requires us to go beyond considering matter as static substance" and leads us "to consider the various ways in which matter changes physical state" as it moves "through, and simultaneously constructs, both space and time." From this historical perspective further studies have now begun rethinking space and territory as the production of specific interests and dynamics from a volumetric and vertical rather than two-dimensional surface plane. As a result, the notion of territory is shifting from issues of legal claims and technical control/surveillance over a surface pane and structure to perspectives that open up the actual materiality of territory and 'terrain' in an effort to widen explanations of why contests over territory exist and paradoxically why protagonists of such contests maintain identical assumptions of territory as a 'thing' to claim or to own. This conceptual, linguistic and notional approach to territory has recently morphed into the significance of regarding space through the language and technologies of terrain, verticality and the volumetric.

Fifth, as Steinberg and Peters $(2015,261)$ have recently argued "(W)hilst the legal control over seas and oceans has been much attended to, in historical 
and contemporary contexts, apprehending its territory as volume presents new discussions. No longer are struggles for space and resources fought on a planar level, relating to the protection of coasts through the security of flat, surface-level sea-territory. Rather contestation has depth. The source of conflict is ever moving and impacted by the movement surrounding it (be it fish, oil, silt, or water molecules themselves)." Thus, materiality "provides a fertile environment" for "rethinking the ways in which our political geographies emerge from" and typically and abstractly "impose themselves on" what is in reality a "dynamic, voluminous materiality." This 'new materialism' emphasises the reality (real realism) and impacts of micro-processes of complex, contingent and sub-atomic entities and physical forms that assemble at specific locations and re-assemble in often random ways. This approach provokes a more radical challenge to the traditional notions of abstract Westphalia space, delineations of water course and water basin, Westphalia legal concepts of sovereignty, politics and agency that are premised on the abstract idea of a rational and centralised sovereign exercising power over a territory understood as a fixed and bounded homogenous space. For Steinberg and Peters $(2015,261)$ this materialism also generates "changing lines of connection" that may "cut through the classic geopolitical assumptions" of lines that are typically "understood as division" of an abstract 'something' into territory (original emphasis). This reorientation is from a world of stable and homogenous surfaces to one of three-dimensional mobilities and undulated surfaces means that territory is not an 'object' but is, in its materiality, formed and re-formed by material and atomic elements (Steinberg 2009). These processes are becoming more self-evident through climate change. For Bennett $(2010,6)$ materiality "can never really be thrown "away" and can challenge the organicist "parts obedient to whole" abstractions, causalities and mechanisms of traditional politics and ethics. Bennett (2010) notes that an assemblage in effect owes its agentic capacity to the vitality of the materialities that constitute it. According to Steinberg and Peters (2015) a rich variety of materialities constitute enables and complicates the construction of territory whilst exerting power in multiple dimensions. This approach then allows a consideration of the various ways in which matter changes physical state as it moves through, and also simultaneously constructs, both space and time. State power therefore works through, under, and over space (Steinberg and Peters, 2014). This churning of material disrupts the idea of separate and fixed plates of territory and the idea of borders as separating territories as a fixed division of 'something'.

Sixth, the matter and physical properties of what is conventionally understood as 'the something' and the border that divides 'it' from other bounded and planar territories are instead understood to be a constant physical and sub-atomic motion. As a result, and of recent interest to IR, for Latour (2005), a thing is always constructed in-relation (original emphasis). The argument for 
Latour therefore is that concepts and 'thing power' is not of a 'something' having relations but of being constantly formed by relations which are not the same kind of relation in evident before localising the event. For Nyers (2012, 3), "In comparison to the vast literature on the movement of people across borders, there is relatively little analysis of the movement of the physical terrain - acts of moving dirt - in border crossings." Here, the question raised is with ascertaining how legal claims might reflect or even manage unstable atomic structures and the 'cosmic eye' in terms of the material relationality between and positioning of sub-atomic particles. A material approach therefore undermines the trajectory of contests ultimately focused on the claiming of 'it' as a bounded space within and over which a surface water flows or inter-state contests over the level at which the abstract 'it' of borders and sovereignty is to be re-negotiated or lessened (water basin).

\section{IMPLICATIONS FOR WATER SECURITY IN THE MEKONG SUB-REGION?}

Firstly, the emphasis on materialism as territory is a potential challenge to the notion of contested sovereign legal claims over abstract territory as a two-dimensional and bounded space. This approach unlocks territory as understood a fixed thing to be shared or divided or bounded and with sovereign power exercised over 'it'. This tension has been endemic to water course and water basin approaches to water security cooperation. The parameters of territorial claims are predicated on a particular lineage of binaries (legal-sociocultural, territory/ecological network and surface/volume). The concept of the 'assemblage', as Bennett (2010) points out, is one in which mobile human and non-human (including molecular) elements and affects are not merely passively consumed but imagined, encountered, and produced. Within an assemblage, materiality persists and is re-formed amidst constant processes of arranging, gathering, mixture and turbulence. Legal and political institutions will always attempt to delimit volumes and delimit horizontal spaces into areas of territory based on facts and fixing boundaries. But as these writers also point out, 'the nature of territory as a political technology' means that 'this process will always be met with a resistance that reflects underlying dynamics that are both social and geophysical.' As a result, the dimensions of space are paramount to the forces of political control. For Steinberg and Peters (2015), the abstract legality of drawing of bounded lines through water in an attempt to constitute levels of legal and sovereign authority fails to account for the dynamic fluidity of the various elements that constitute the marine assemblage. Thus, the fluid lines of connection cut through the Westphalian and geopolitical lines of division and can 
create distinct opportunities for both the projection of, and yet resistance to, power as visuality, surveillance and control. Thus, whilst the boundaries of landed states and places may politically and materially shift as noted by Nyers (2012), in the process, the actual material constituents and atomic structure of the land. This means that minute and sub atomic particles may also have different types of sovereignty exercised over them as specific assemblages of materials at specific points in time and that challenge abstract law, abstract time and abstract sovereignty endemic to Westphalian states.

Secondly, once the myriad of legal and historical contestations are understood as sharing similar assumptions then alternative spaces can perhaps be approached. This would potentially mean that the 'realism' of inter-state territorial disputes become increasingly unable to cope with the reality of the 'shifting sands' of the anthropocene. This means that Westphalian and territorial boundaries become understood not as dividing 'something' into something known and practiced chronologically as territory but as shifting lines of connection where the lines of connection are merely the observably manifestations of sub-atomic structure assemblages in constant motion. This constant, uncertain and random shifting of material and sub-atomic particles provides a fertile environment for reconceptualising understandings of space and time that are used in territorial claims and the legal process. By unlocking geological structures of terrain then it is possible that Westphalia abstractions and binary choices might be identified as increasingly unrealistic. Materiality also emphasises material fluidity and a challenge to distinctions between land and water, between the states of water as solid, liquid and gas, and movements which makes a different diplomacy possibility and perhaps based on fixed binaries and diplomatic trade-offs increasingly and paradoxically unrealistic.

Thirdly, this potentially challenges the traditional spatial set-up of the water course and water basin approach (or at least the assumptions of territory and sovereignty therein). Territory now becomes understood as physical silt and water molecules themselves, fibrous, wiry, threadlike ropy and capillary and can never be captured by abstract notions of layers, structures, territories or spheres. What are defined as water rights and issues of sovereign control as per the water course approach is ultimately based on being able to measure the actual rate of water flow in specific time and space within a bounded territory and as a political-legal context within territorial boundaries (and boundaries that initially delineate what becomes a territory). An understanding of the subterranean and role of infrastructure impact on that rate and the changing location of the river itself impacts both on traditional approaches and opens up alternative definitions of water rights as a material approach. The Mekong river potentially could be diverted underground to be used for effective storage and thus impacting on river flow. Technically the Mekong river could then in effect 'disappear' from the 
surface. Dam building and such infrastructures could therefore be used to artificially change the rate of flow in a diversion that is not based on compass coordinates but on the subterranean. Storage facilities could also theoretically be built underground to secure sediments and thus leading to a whole swathe of 'surface' legal issues regarding the role of subterranean space, rock formations and newly connected underground caves underneath the traditional surface borders. The new materialism potentially opens these issues into genuine legal matters inverts the territorial hierarchies of upstream and downstream even as actual material from upstream is lodged as downstream silting and literally taking terrain and territory from upstream. For Elden $(2017,10)$ "all attempts at fixing boundaries and shaping territories are complicated by dynamic features of the earth including rivers, oceans, polar regions, glacier, airspace and subsurface." What happens therefore, he asks, and even based on familiar IR assumptions of what a boundary is and creates, if a river changes direction and from this how can the distinctions be made between a genuine or artificial diversion (and who defines this). Moreover, what if an island is built up from slowing sediment and emerges in the middle of a river with regards to territorial rights or the river dries up and thus ends up altering the site of the 'thalweg' (the deepest part of a river and often understood as an international boundary below the surface). A new materialism perspective then breaks down such hierarchies between genuine and artificial, human and non-human. As Fox and Sneddon (2019) point out for instance, Thailand may lose a 'traditional' territory as a result of the dredging of rapids on the Lancang (Mekong) river water course which is creating a shift in the international boundary. To make the Mekong river more navigable for trade it is suggested that territory is going to be lost (or ceded) not through a foreign occupation or invasion but from domestic economic development strategies, in turn conceivably forcing up land prices. Mining and constructing dykes also mean that if a sediment supply to the Mekong delta is completely cut off then the Mekong Delta itself will disappear as a material entity and so state territory becomes a blank and abstract space with unproductive 'real' land whilst still being 'territorially integral' in the abstractions of the Westphalia state system.

Fourth, in this respect, awareness of the physical materiality and the material 'dirt' as a result of river activity has seemingly opened questions regarding the mapping of the region through abstract Westphalia principles of a bounded territory with sovereignty exercised over 'it'. The emphasis on the 'geo' of geopolitics maintains a world of perpetual immanence that is worked upon by outside forces and, therefore, such conceptualisations are still reliant on a linear trajectory of time that stabilises history into material strata and immaterial epochs that can be neatly bordered, bounded, and contained - marking one material layer and social era from another. In other words, it is the chaotic movement and reformation of matter that both enables and disrupts (or reterritorialises and 
deterritorialises) geological striations. This approach to the concept of territory as a non-determinate and non-planar disturbs Westphalia assumptions of territory as fixed and surface homogenous that have been crucial to inter-state and sovereign legal claims in the water course approach. This geological elementality seeps into both the life sustaining act of water as well as the sovereign act of territorially establishing national infrastructures. This constant shifting of (and through) material movement (and the movement of materiality) also provides a fertile environment for reconceptualising understandings of space, time and movement. To some extent, the opportunity to revitalise a materiality approach can also be linked, it is being suggested here, to utilise different versions of development, territory and sovereignty. Territory now becomes understood as physical silt and water molecules themselves, fibrous, wiry, threadlike ropy and capillary and can never be captured by abstract notions of layers, structures, territories or spheres.

Finally, the material approach implies that there are no fixed spatial hierarchies between the global or the local or between abstract structures of the macro or micro levels. Instead, there are the changing and shifting densities of vibrant material networks and network connectors as human and nonhuman subjects and objects mold and fold across and emerge so that space and place is forever in formation as gathering mixtures. What the new materialism approach provides is both an explanation as to why these contradictions occur and with this acceptance the opportunity to redesign diplomatic procedures on the basis of the real geology of land and borders. This generates a growing awareness of the physical materiality and 'dirt' of territory in that the material parts that compose 'it' are heterogeneous and independent and it is from the unstable and assemblage relations between these material parts that the notion of a temporary and contingent 'homogenous' whole emerges and vanishes. As a result, bubbles, foams and parcels of water are turbulently exchanged between one part of the moving fluid and another. This geological elementality further and physically seeps into both the life sustaining act of water as well as the sovereign act of territorially establishing and constructing national infrastructures. Indeed the construction of water distribution pipelines and dams on the Mekong (justified by states as policies of water security) now uncover and unravel vast swathes and spaces of vibrant materiality as a once underground geology of rock and materials seep out onto the surface whilst simultaneously disturbing the legal and spatially hierarchical distinctions that are typically made between Westphalia surface space (demarcated territory) and what is unseen and under the surface. As a result, the very notion of spatial segregation between upstream or downstream state becomes problematic. This complex assemblage process is constantly occurring around material objects (such as rocks) and producing voluminous and vociferous vortices. This means that the geological materials are twisted and 
churned by inseparable currents and counter-flows so that the 'it' object (rock) of which legal territorial claims and boundary procedures are based and made become, in reality, unstable and beyond state rationality. The impact of storms and flooding and the material washing away of key land nutrients, soil, minerals and resources is also leading to a realization that the reality of what counts as land itself and given its volumetric quality cannot be captured in the two-dimensional mappings of territory that have framed 'realist' diplomatic efforts at cooperation at water security over what counts as the Mekong river and basin.

\section{CONCLUSION}

The paper is not suggesting that these new materialism approaches processes will become the 'new critical norm' and it is doubtful that the new materialism community would want to be. Established realist-based routines of river management policy making still make familiar territorial assumptions about sovereignty that underscore water course and water basin responses and associated sites of diplomacy. These are prevalent in the water course approach. As a perspective on knowledge and human interests from Jurgen Habermas, and taken to IR by writers such as the late Robert Cox amongst others, theory is ideologically understood to justify (and universalize) the political interests of a specific group and for a specific political purpose under the guise of technical 'problem solving' expertise in a prevailing world order. Water security policymakers often use Western state-centric realism aiming to provide an elite based epistemic community with knowledge status, legitimacy and global credibility. This can at times be regarded as a resistance to increasing Chinese influence in the region. Yet a new materialism approach does highlight the growing dislocation between abstract Westphalian notions of law and territory and the material reality of climate change. Paradoxically, this material reality is 'more real' than realist approaches to territory and sovereignty and the more the Westphalian norms of territorial demarcated state-based legalistic sovereignty are used (either reinforced or 'pooled') then it is being suggested here that the more this gap is becoming apparent in the Anthropocene. It is already being gradually acknowledged in the traditional sphere of water security and policymaking that material processes are undermining the very notion of fixed borders. Climate change and impact on river flows has been understood in traditional Westphalia terms. These conventional notions and terms of territory and sovereignty have framed the choices and options regarding inter-state relations in the sub-region over water security between water course and water basin state responses. These, over time, have become styled as the realist and liberal approaches. Clearly 
within these frameworks there are different variations but the actual architecture has remained pretty solid and recognized as such. The paper has introduced the notion of new materialism to this debate as a more realistic way, and increasingly recognized, as reflecting real shifts in the actual and particle-based make up of land and terrain itself as a churning materiality rather than a fixed and surface territory upon which and within which a river flows. Indeed the very notion of what counts as a 'flow' of water is problematic in a new materialism agenda. It is suggested here that the realism/liberal debate (framed as water course and water basin in water security) is intentionally or not (or as an unintended consequence of conventional policy bottlenecks/gridlock) being questioned by climate change and the new material approaches that might add a more pragmatic and realistic approach to water security diplomacy and policymaking in theory and practice.

\section{ACKNOWLEDGEMENTS}

This work was supported by a POSCO ‘Asian Studies’ TJ PARK Foundation Grant.

\section{REFERENCES}

Adger, W Neil. 2000. "Social and Ecological Resilience: Are They Related?" Progress in Human Geography 24(3): 347-364.

Agnew, John. 1994. "The territorial trap: the geographical assumptions of international relations theory." Review of International Political Economy 1(1): 53-80.

Anderson, Ben and Colin MacFarlane. 2011. "Assemblage and Geography." Area 43(2): 124-127.

Anderson, Ben, M. Keanes, C. McFarlane and D. Swanton. 2012. "On Assemblages and Geography." Dialogues in Human Geography 2(1): 171-189. DOI: 10.1177/2043820612449261

Allen, John. 2011. "Powerful assemblages?" Area 43(1): 154-157.

Antonsich, Marco. 2009. "On territory, the nation-state and the crisis of the hyphen." Progress in Human Geography 33(5): 789-806.

Antonsich, Marco. 2010. "Rethinking Territory." Progress in Human Geography 35 (3): 422-425.

Antonsich, Marco. 2016. "Book Review: The Birth of Territory." Progress in Human Geography 40(2): 152-154.

ASEAN. 2016. "Master Plan on ASEAN Connectivity 2025." ASEAN, accessed May 20 2020, https://asean.org/storage/2016/09/Master-Plan-on-ASEAN-Conne ctivity-20251.pdf 
Bennett, Graham and Kalemani, Jo Mulongoy. 2006. "Review of Experience with Ecological Networks, Corridors and Buffer Zones." Secretariat of the Convention on Biological Diversity, Montreal.

Bennett, Jane. 2010. Vibrant Matter North Carolina: Duke University Press.

Beurskens, Kristine and Miggelbrink, Judith. 2017. "Special Section Introduction

- Sovereignty Contested: Theory and Practice in Borderlands." Geopolitics 22(5): 749-756,

Brighenti, Andrea. 2010. "On Territorology Towards a General Science of Territory." Theory, Culture and Society 27(1): 52-70.

Bandyopadhyay, Jayanta. 2013. "Securing the Himalayas as the Water Towers of Asia: An Environmental Perspective." Asia Policy 16(1):45-50.

Benson Charlotte, Twigg John, and Myers M. 2001. "NGO initiatives in risk reduction: an overview." Disasters 25(3):199-215.

Bingham, Graham, Aaron W, and T. Wohlgenant. 1994. Resolving Water Disputes: Conflict and Cooperation in the U.S., Asia, and the Near East. Washington, DC: U.S. Agency for International Development.

Blackbourn, David. (2006). The conquest of nature: Water, landscape and the making of Modern Germany. London: Jonathan Cape.

Dalby, Simon. 1992. "Ecopolitical Discourse: 'Environmental Security' and Political Geography." Progress in Human Geography 16(4): 503-522.

Elden, Stuart. 2010. "Land, Terrain, Territory." Progress in Human Geography 34(6): 799-817.

Elden, Stuart. 2013. "Secure the Volume: Vertical geopolitics and the depth of power." Political Geography 34(1): 35-51.

Elden, Stuart. 2013a. The Birth of Territory. Chicago: Chicago University Press.

Elden, Stuart. 2017. "Legal Terrain: The Political Materiality of Territory." London Review of International Law 5(2): 1-26.

Endfield. Georgina H. and Carry Van Lieshout. 2020. "Water and Vertical Territory: the volatile and hidden historical geographies of Derbyshire's lead mining soughs, 1650s-1830s." Geopolitics 25(1): 65-87.

Fox, Coleen and Christopher S. Sneddon. (2019). "Political Borders: Epistemological Boundaries, and Contested Knowledges: Constructing Dams and Narratives in the Mekong River Basin." Water 11(3): 413-430.

Gleick, Peter H. 1993. "Water and Conflict: Fresh Water Resources and International Security." International Security 11(1):79-112.

Gleick, Peter H. 1998. The World's Water 1998-1999: The Biennial Report on Freshwater Resources. Washington, DC: Island Press.

Grey, David and Sadoff, Claudia W. 2007. "Sink or Swim: Water security for growth and development." Water Policy 9(6): 545-571.

Latour, Bruno. 1992. "Where are the missing masses? The sociology of a few mundane artefacts." in Bijker, Wiebe. E and John Law (eds) Shaping 
Technology/Building Society. Studies in Sociotechnical Change. Cambridge, MIT Press, 225-258.

Latour, Bruno. 1999. Pandora's Hope: Essays on the Reality of Social Studies Cambridge MA: Harvard University Press.

Latour, Bruno. 2005. Reassembling the social: an introduction to actor network theory. Oxford: Oxford University Press.

Magsig, Bjorn-Oliver. 2015. "Water security in Himalayan Asia: first stirrings of regional cooperation?" Water International 40(2): 342-353.

Manyena, Siambabala Bernard. 2006. "The Concept of Resilience Revisited." Disasters 30 (4): 434-450.

Mavelli, Luca. 2016. "Governing the Resilience of Neoliberalism Through Biopolitics." European Journal of International Relations 23 (3): 489-512.

Mekong River Commission (MRC). 1995. Agreement on the Cooperation for the Sustajnable Development of the Mekong River Basin. Mekong River Commission Secretariat, Bangkok, Thailand.

Mollinga, Peter P. (2008). "Water politics and development: Framing a political sociology of water resources management." Water Alternatives 1(1): 7-23.

Muller, Martin. 2015. "Assemblages and Actor Networks: Rethinking socio-material power, politics and space." Geography Compass 9(1): 27-41.

Neocleous, Mark. 2012. "Don’t Be Scared, Be Prepared: Trauma-Anxiety-Resilience." Alternatives: Global, Local, Political 37 (3): 188-198.

Nyers, Peter. 2012. "Moving Borders." Accessed 15 November 2019 https://www. radicalphilosophy.com/commentary/moving-borders.

OECD. 2013. "Water Security for Better Lives: A Guide for Policymakers." Accessed 19 May 2020 https://www.oecd.org/env/resources/Water\%20Security $\% 20$ for\%20Better\%20Lives-\%20brochure.pdf

Paladini, Stefania. 2012. "Evaluating Water Security in the Asia-Pacific Region: A New Approach Based on Vulnerability Indices.” Eurasian Geography and Economics 53(1): 95-114.

Pink, Ross M. 2016. Water Rights in Southeast Asia. Basingstoke: Palgrave Macmillan.

Rieu-Clarke, Alistair. and Geoffrey D. Gooch. 2010. "Governing the tributaries of the Mekong: The contribution of international law and institutions to enhancing equitable cooperation over the Sesan." Pacific McGeorge Global Business \& Development Law Journal 22(2): 193-224.

Shah, Nisha. 2011. "The Territorial Trap of the Territorial Trap: Global Transformation and the Problem of the State's Two Territories." International Political Sociology, doi: 10.1111/j.1749-5687.2011.00144.

Shaw, Rajib. (Ed.) 2014. Community Practices for Disaster Risk Reduction in Japan. Tokyo: Springer Press.

Sohn, Christopher. 2016. 'Navigating borders' multiplicity: the critical potential 
of assemblage." Area 48(2): 183-189.

Steinberg, Philip E. 2009. "Sovereignty, Territory, and the Mapping of Mobility: A View from the Outside." Annals of the Association of American Geographers 99(3): 467-495.

Steinberg, Philip. E. 2013. "Of other seas: metaphors and materialities in maritime regions." Atlantic Studies 10(2): 156-169.

Steinberg, Philip E. and Peters, K. 2015. "Wet Ontologies, Fluid Spaces: Giving Depth to Volume through Oceanic thinking." Environment and Planning D 33(2): 247-264.

Stilz, Alan. 2009. "Why do states have territorial rights?" International Theory 11(2): 185-213.

United Nations Development Programme. 2004. Reducing Disaster Risk: A Challenge for Development: A Global Report. United Nations Development Programme, New York.

United Nations Office for Disaster Risk Reduction (UNISDR). 2009. "UNISDR Terminology on Disaster Risk Reduction." Geneva, accessed 24 November 2019 http://www.unisdr. org/we/inform/terminology.

UN Water. 2013. "Defining Water Security." https://www.unwater.org/publications/ water-security-infographic/ Accessed 20 May 2020

Usher, Mark. 2019. "Territory incognita." Progress in Human Geography DOI10.1177/0309132519879492 